\title{
Under Interruptive Effects of Rarity and Mental Accounting, Whether the Online Purchase Intention Can Still Be Enhanced Even with Higher Search Costs and Perceived Risk
}

\author{
Shu-Yi Liaw ${ }^{1} \&$ Thi Mai Le ${ }^{2}$ \\ ${ }^{1}$ Management College, Computer Centre, National Pingtung University of Science and Technology, Taiwan \\ ${ }^{2}$ Department of Tropical Agriculture and International Cooperation, National Pingtung University of Science and \\ Technology, Taiwan \\ Correspondence: Thi Mai Le, Department of Tropical Agriculture and International Cooperation, National \\ Pingtung University of Science and Technology, Taiwan. E-mail: lemai.istnu@gmail.com \\ Received: June 20, 2017 \\ Accepted: July 16, 2017 \\ Online Published: July 18, 2017 \\ doi:10.5539/ijbm.v12n8p160 \\ URL: https://doi.org/10.5539/ijbm.v12n8p160
}

\begin{abstract}
The purpose of this study was to explore the impact of search costs and perceived risk to online buying intention under the moderators of rarity and mental accounting in marketing practices. In this study, four types of online products food, toys, travelling and clothing were divided into pre-test and post-test to observe the rarity and mental accounting conditions. To investigate this study a survey was conducted with a sample size of 473 college students. The results found that (1) without moderators, search costs and perceived risk had no significant effects on purchase intention but had a positive significant effect on purchase intention under the interruptive effects of rarity and mental accounting. (2) In rarity moderator, online customers are more sensitive to limited time than limited quantity. (3) In mental accounting interruption, pay less and get more had significant moderating effects. (4) Limited time and get more had the highest contribution to an improvement in purchase intention. Contributions of this study provide to relevant businesses or network operators considerations of rarity and mental accounting in online promotion strategy implementation.
\end{abstract}

Keywords: Purchase intention, search costs, perceived risk, rarity, mental accounting

\section{Introduction}

Due to changing consumption habits, the behavior of shopping gradually transformed from online shopping convenience to consumers paying attention to their shopping efficiency. Considering the time it takes to find a product for purchase and online transactions security. Online shopping is an internet based digital economy. However, consumers cannot access all the information on the web, which presents some risks (Ratchford, 1982). For example: missing information, product not meeting expectation, losing personal data and lengthy delivery time. These consequences may make consumers feel unpleasant, leading to perceived risks of online shopping. The suppliers do forward in many marketing strategies, such as improving customer demand for its products or limited number of products which lead rarity of products and customers want to meet their demand, they must pay a higher price (Verhallen, 1982). Thaler (1985) created a new model for consumer behavior based on cognitive psychology to design a corresponding promotional technique which improved customers' mindset on a product's value and make consumers feel happier.

During the online shopping process, customers consider many factors which can influence their purchase intention. Considering these factors, consumers may feel that the goods are necessities and urgency of purchase may result in overlooked search costs and perceived risks. Consumers, usually will able to reduce their willingness to buy products when they receive high search costs or high perceived risk. However, these conditions may change with promotions. E-vendors have launched different promotion programs like using the rarity approach as a method to motivate customers desire to buy products. There are two types of rarity used in this study (Gierl, Plantsch, \& Schweidler, 2008; Verhallen, 1982; Verhallen \& Robben, 1994). Therefore, this study is intended to understand how the rarity situation affects customers' behavior. Online shopping sites generally introduce many promotional strategies to affect the psychological feelings of consumers. The mental account is originally proposed by Thaler (1985), and its study is continued (Duxbury, Keasey, Zhang, \& Chow, 
2005; Helion \& Gilovich, 2014; Ho Ha, Suk Hyun, \& Pae, 2006; Reinholtz, Bartels, \& Parker, 2015). Mental accounting means that besides actual account, there is another account in customers' mind. Two classes of mental accounting; pay less with discount price and gain more by receiving other gifts or services are conducted in this study. The AIDA hierarchical model is used to measure the effectiveness of advertising (Ehrenberg, 2000; T.-R. Lee, Lin, Liao, \& Yeh, 2013). An effective marketing strategy can be represented by impulse buying and impulse buying is one of the most important determinants of company outcome(Xiao \& Nicholson, 2013). The AIDA model was developed to measure four stages: Attention, Interest, Desire, and Action of their customers in the selling process. First step is attracting customers' attention on the website or products. For the attention of people, there are many ways like as controversial or shocking content can be ways to attract visitors to our promotional message. Second step is generating customers' interest make them to demonstrate product features and benefits and get interested in their product. Third step is to create enthusiasm in the people that the products are under some special conditions. Forth step is to end the purchase or sale at this stage of the customer you want to know about buying, and to take its final decision to end the process.

According to research motivations, the purposes of this study are as followings: Firstly, examination the influence of search costs and perceived risk to consumer are online purchase intention. Secondly, under rarity situation, whether it will impact the relationship of search costs and perceived risk the relationship of purchase intention. Thirdly, in the case of mental accounting situation, whether its impact to search costs and perceived risk to purchase intention.

\section{Literature Review}

\subsection{Factors Affect Online Customers' Purchase Intention}

Dodds, Monroe, and Grewal (1991) argued that purchase intention is the likelihood that consumers are willing to buy the product. The higher the perceived value it is more likely customers will purchase the product. In marketing research, the purchase intention is often used as a measure of the purchase behaviour (Morwitz \& Schmittlein, 1992). Customer purchase intention represents consumers after careful assessment, the possibility that consumers will plan or be willing to purchase certain products or services available on the site. In general, the consumers' consideration to buy products is based on many factors such as product information; product display and price are all important reference messages. Bhattacherjee (2002) stated that customers' trust in web site affects their willingness to use their services. When customers have high trust, they have higher willingness to carry out online transactions. Beatty and Smith (1987), defined that information search is a degree of attention. Awareness adds effort to obtain information about particular purchasing activity under consideration. Information search can be divided into internal information search and external information search. Information search efforts are efforts to obtain information from outside, and this external information search is for the first time that consumers are seriously considering buying and ending with actual purchases (Srinivasan \& Ratchford, 1991). Search costs include time costs, money, costs for searching effort, and psychological costs of processing information. Searching costs are time and effort used to search for relevant products or services information and making comparisons of price or other attributes among different online stores (Teo \& Yu, 2005). Customers may be affected by search costs during the first transaction process with an e-vendor (Lynch Jr \& Ariely, 2000). Besides monitoring costs and adapting costs, search costs is one of the important indicators of transaction costs (Teo \& Yu, 2005). Customers will decide transaction method is economical on perceived transaction costs (Wigand, 1997). Consumers' acceptance decision is affected by the transaction costs (Liang \& Huang, 1998). Therefore, we hypothesized that:

Hypothesis $\left(\mathbf{H}_{\mathbf{1 - 1}}\right)$ : Search costs have a negative impact on purchase intention.

The concept of perceived risk was initially defined as the feeling of uncertainty customers experience when they cannot foresee the consequences regarding a purchase decision, being incorporated in researches concerning the consumer behavior. Forsythe and Shi (2003), stated that online consumers may face four kinds of perceived risk such as privacy, performance, financial and time risk. Privacy risk is defined as the probability of having disclosed privacy information as a result of online transactions (Garbarino \& Strahilevitz, 2004). Time risk is defined as the possibility and the importance of losing time when shopping online. Even with the advantage of shopping at any time, online shopping still raises the time risk because shoppers may experience difficulty navigating websites, submitting orders, and finding appropriate goods. Financial risk is defined as the likelihood of money loss aroused from online shopping. Performance risk may be the result from a poor product choice or the value of the product lower than expected. Market research has reported that there are growing concerns about perceived risk associated with online shopping. Pires, Stanton, and Eckford (2004)implied that perceived risk has been negatively associated with purchase intention. The lower perceived risk of shopping at the online retailer, the greater consumers' 
purchase intention toward the online retailer (Kim \& Lennon, 2013).Therefore, we propose the hypothesis:

Hypothesis $\left(\mathbf{H}_{\mathbf{1 - 2}}\right)$ : Perceived risk has a negative impact on purchase intention.

\subsection{The Moderating Role of Rarity}

Greenwald (1968) illustrated the Commodity Theory, stating that any difficulty to obtain goods, will contribute to a higher rating. Marketing view scarcity appeal as an important strategy (Brannon \& Brock, 2001). Marketing strategy architects provide a variety of rarity strategies (Gierl et al., 2008) divided into two types: Limited quantity, caused by the demand for more than the supply of the product and limited time, a period that limits the availability of the product. The combination of commodity and reaction theory could define rarity as consumers believe that the product is difficult to obtain, it will motivate their desire to get the product. Hence, their purchase intention will be affected by the rarity of products. The rarity of time can only be due to the supply side, because in this context the e-vendor states the time restriction on the outset of the offer by stating a more or less precise borderline of product or service availability. In order to satisfy customers' need in the case of rarity, products become an attractive option to communicate uniqueness (Amaldoss \& Jain, 2005) and motivate customer's desire (Jung \& Kellaris, 2004). According to Gierl and Huettl (2010), scarcity makes a product appear more attractive and have a positive effect on consumers response. Consumers were affected by the advantage of limited time and the feeling of not having enough time to make a purchase during promotion period (Simonson, 1992). Similarly, Aggarwal, Jun, and Huh (2011) also indicated that consumers had a higher willingness to buy and a lower intent to search for a better deal under the limited time offer condition. Motivation from this research followed the considerations of the following hypotheses:

Hypothesis $\left(\mathbf{H}_{2-1}\right)$ : Rarity (Limited time) acts as a moderator variable between search costs and purchase intention.

Hypothesis $\left(\mathbf{H}_{2-2}\right)$ : Rarity (Limited time) acts as a moderator variable between perceived risk and purchase intention.

Limited-edition products were designed as a marketing strategy to intensify customer desire and intention to purchase them (Wu, Lu, Wu, \& Fu, 2012). Castro, Morales, and Nowlis (2013) investigated that limited availability by itself is a signal to lead products more valuable. This study wants to estimate the interruptive effect of limited quantity to the relationship between search costs, perceived risk and purchase intention. The following hypotheses are considered:

Hypothesis $\left(\mathbf{H}_{2-3}\right)$ : Rarity (Limited quantity) acts as a moderator variable between search costs and purchase intention.

Hypothesis $\left(\mathbf{H}_{2-4}\right)$ : Rarity (Limited quantity) acts as a moderator variable between perceived risk and purchase intention.

\subsection{The Moderating Role of Mental Accounting}

Mental account or mental accounting is a cognitive process in purchasing activity. Thaler (1985) pointed out that money falls under the category of mental accounting but does not completely substitute money in another account. Theory of mental accounting is put forward in an incomplete alternative theory. It does not only explain people's behavior, but also predicts the psychology of consumers. Many previous studies indicated that mental accounting had effect on customer decision making (Duxbury et al., 2005; Helion \& Gilovich, 2014; Ho Ha et al., 2006). Liao and Chu (2013)investigated the mental accounting related to buying a new product given different levels of awareness of the possibility of reselling and buying similar, different, or identical products. Promotion is divided into two categories according to incentives (Campbell \& Diamond, 1990). The first is a significant reduction in prices, such as discounts, coupons, ease of integrating the price of a product, called "pay less". Fry and McDougall (1974) pointed out that the higher the discount, the more consumers will think that the price he or she paid is the lowest price; or when the purchase of goods with additional goods and services bought together the higher the value. This then contributes to consumers thinking that the purchase of this product is the best choice. The following hypothesis is suggested:

Hypothesis $\left(\mathbf{H}_{3-1}\right)$ : Mental accounting (pay less) acts as a moderator variable between search costs and purchase intention.

Hypothesis $\left(\mathbf{H}_{3-2}\right)$ : Mental accounting (pay less) acts as a moderator variable between and purchase intention.

Another way, non-money promotions are usually considered segregated in the purchasing price of the original product, in the form of gifts, free shipping or promotion for next time. Interests is independent with main product, is called "get more". Reinholtz et al. (2015) studied get more by gift cards change customers' responses. Under 
motivation of this study, we purpose the hypotheses:

Hypothesis $\left(\mathbf{H}_{3-3}\right)$ : Mental accounting (get more) acts as a moderator variable between search costs and purchase intention.

Hypothesis $\left(\mathbf{H}_{3-4}\right)$ : Mental accounting (get more) acts as a moderator variable between perceived risk and purchase intention.

\section{Methodology}

\subsection{Research Design}

This study focuses on the impact of search costs and the perceived risk on the purchase intention when consumers are making online purchases under time rarity and mental accounting conditions. Figure 1 is a development model of this study according to the study purpose. The experimental manipulation of this study is divided into rarity and mental accounting. Research products are divided into food, toys, tourism and clothing. Food, toys, travelling and clothing were used to design the experiment. Representing categories which have dynamic promotional activities to attract consumers on websites. Specifically food and toy products, where e-vendors often use limited time or limited quantity compared with other products. Alternatively, travelling and clothing, e-vendors often use discount price or provide gifts or services as their promotional actives to attract consumers.

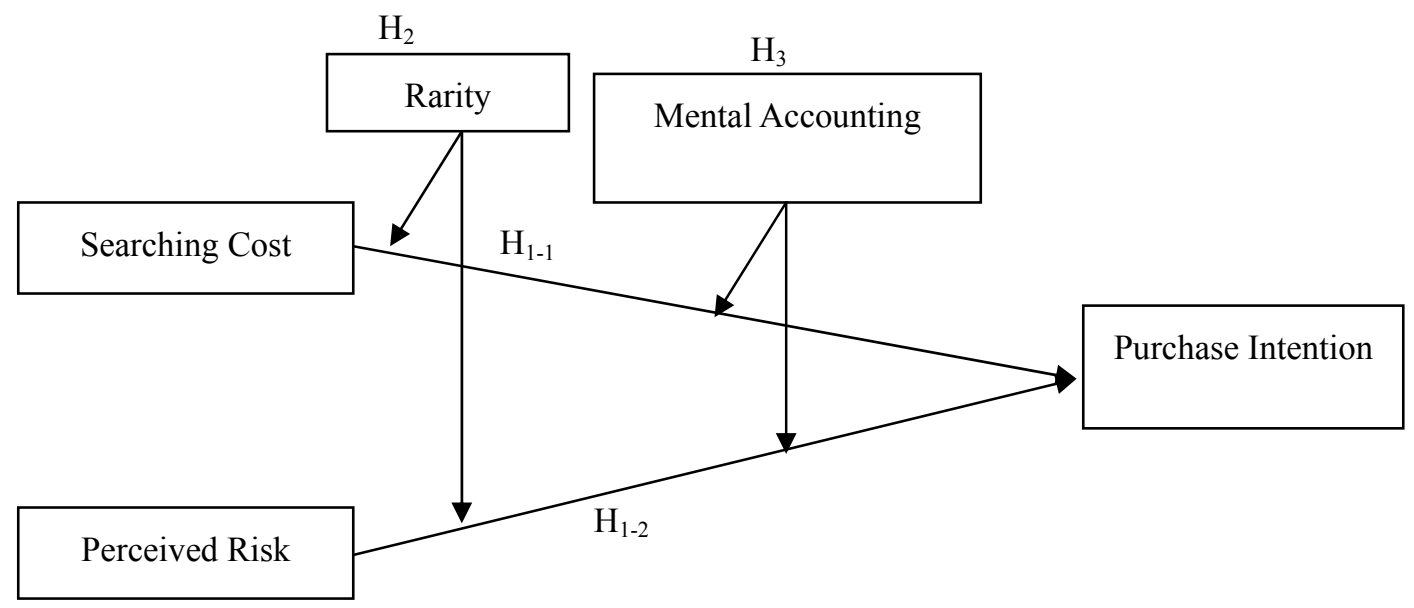

Figure 1. Research Model

\subsection{Experimental Design}

Two interruption moderators were used to design this experiment. Rarity is implemented into limited time and limited quantity. Mental accounting is operated into pay less and gets more. In order for clarity of the respondents the conditions of the questionnaire, this study manipulated four product types. In this experimental design, the pretest measurements are omitted because the participants are measured only once and its simplicity of this design makes it more attractive than the pretest-posttest control group design (Cooper, Schindler, \& Sun, 2003).

Table 1. Rarity experimental manipulation

\begin{tabular}{lll}
\hline & Experiment Treatment & After test \\
\hline Control group & $\mathrm{X}_{10}$ & $\mathrm{O}_{10}$ \\
Group 1 (Limited time) & $\mathrm{X}_{11}$ & $\mathrm{O}_{11}$ \\
Group 2 (Limited quantity) & $\mathrm{X}_{12}$ & $\mathrm{O}_{12}$ \\
\hline $\mathrm{X}_{10}:$ No rarity manipulation; & & $\mathrm{O}_{10}:$ No rarity manipulation after test \\
$\mathrm{X}_{11}:$ Limited time manipulation & & $\mathrm{O}_{11}:$ Limited time manipulation after test \\
$\mathrm{X}_{12}:$ Limited quantity manipulation & & $\mathrm{O}_{12}:$ Limited quantity manipulation after test
\end{tabular}


Table 2. Mental accounting manipulation experiment

\begin{tabular}{lll}
\hline & Experiment Treatment & After test \\
\hline Control group & $\mathrm{X}_{20}$ & $\mathrm{O}_{20}$ \\
Group 1 (Pay less) & $\mathrm{X}_{21}$ & $\mathrm{O}_{21}$ \\
Group 2 (Get more) & $\mathrm{X}_{22}$ & $\mathrm{O}_{22}$ \\
\hline $\mathrm{X}_{20}:$ No mental accounting manipulation & $\mathrm{O}_{20}:$ No psychological manipulation after test \\
$\mathrm{X}_{21}:$ Pay less manipulation & & $\mathrm{O}_{21}:$ Pay less manipulation after test \\
$\mathrm{X}_{22}:$ Get more manipulation & & $\mathrm{O}_{22}:$ Get more manipulation after test
\end{tabular}

In this study, we designed an experiment as two constraints of rarity which are limited time and limited quantity situation (Gierl et al., 2008). Limited time is explained that the online page indicates "Limitation only in Children's Day or Valentine's Day", which means that it will appear only during a special season, on a special holiday or in one short period of time. Limited quantity means the online page indicates "limited 100 products/services or only five groups", which means that the quantity of goods is fixed and is no longer available after being sold out.

The experimental design for mental accounting is according to (Campbell \& Diamond, 1990), divided into pay less or get more. Pay less indicates that online page marked "price discount". Example, original price is 100 USD, but with $20 \%$ discount price, it is just 80 USD. Get more means the online page indicates "buy one get one", or "free shipping".

\subsection{Measurement}

Table 3. Operationalization of constructs

\begin{tabular}{lll}
\hline Construct & Dimensions & Sources \\
\hline \multirow{2}{*}{ Search costs } & 1. Time costs & (Bettman, 1979); (Schmidt \& Spreng, 1996) \\
$\left(\mathrm{X}_{1}\right)$ & 2. Physiological costs & \\
& 3. Psychological costs & \\
& 1. Financial risk & (Forsythe \& Shi, 2003); (Featherman \& Pavlou, \\
Perceived risk & 2. Performance risk & 2003; Kuhlmeier \& Knight, 2005; Stone \& \\
$\left(\mathrm{X}_{2}\right)$ & 3. Privacy risk & Grønhaug, 1993) \\
& 4. Time risk & \\
1. Attention & (Zeithaml, 1988); (Dodds et al., 1991) \\
$(\mathrm{Y})$ & 2. Interest & \\
& 3. Desire & \\
\hline
\end{tabular}

\subsection{Sample Size and Data Collection Procedure}

Picture test

In order to ensure the validity of a self-made picture, a pretest evaluation of a self-made picture and text describing the situation were tested before doing the actual experiment. The test results ( $t$-value ranged from 2.161 to $5.851 ; p<0.05)$ indicated that the situation picture and its contextual effects were valid and achieved its purpose.

\section{Procedure}

Respondents had to interact with the virtual store with the questionnaire to complete the survey. Figure 2 to figure 9 are the interface of the virtual store. The virtual store environment was designed in a manner in which participants could understand and record their answers. After interacting with the virtual store layout, respondents were assigned to answer the survey. 


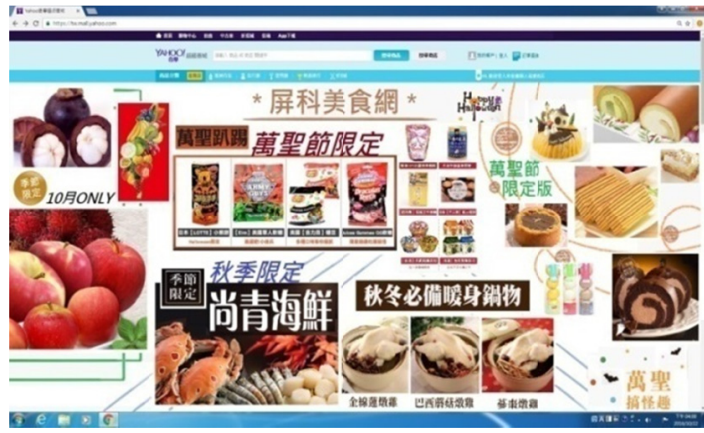

Figure 2. Limited time manipulation in food

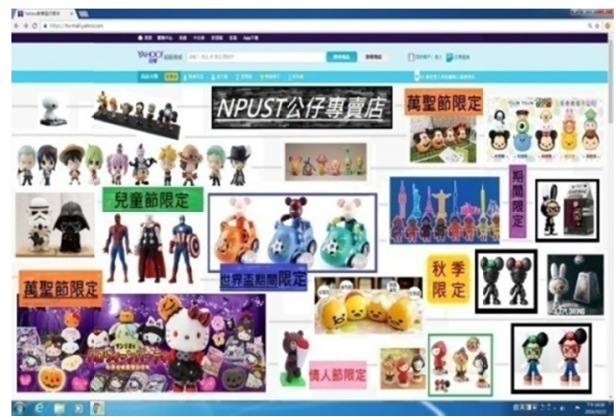

Figure 3. Limited time manipulation in toys

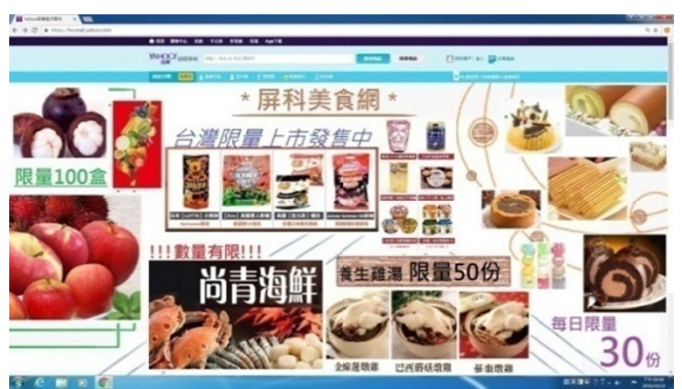

Figure 4. Not limited time manipulation in food

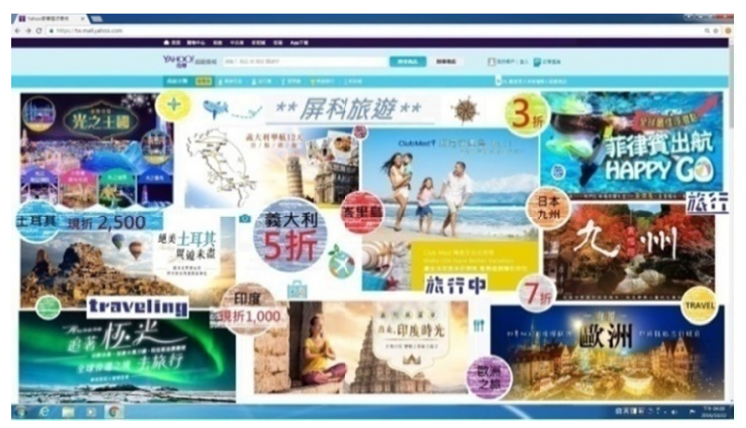

Figure 6. Pay less manipulation in travelling

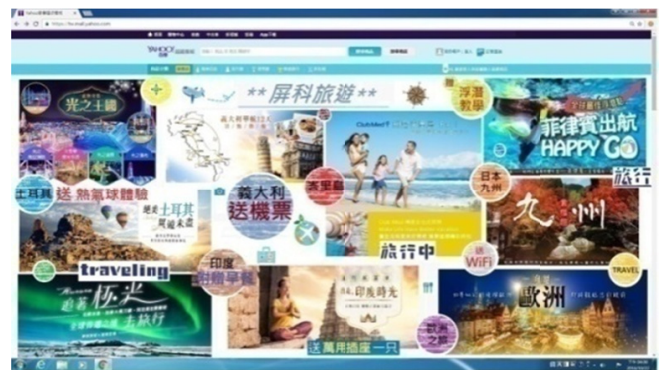

Figure 8 . Get more manipulation in travelling

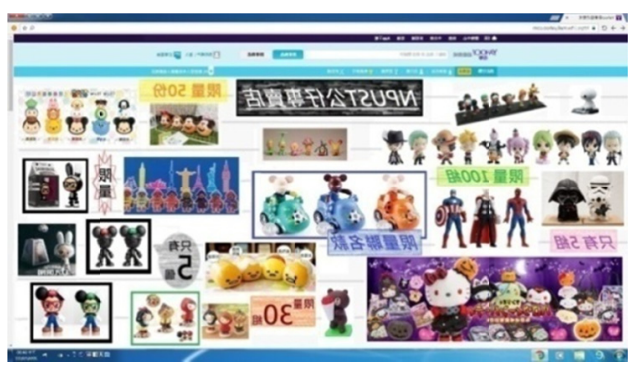

Figure 5. Not limited time manipulation in toys

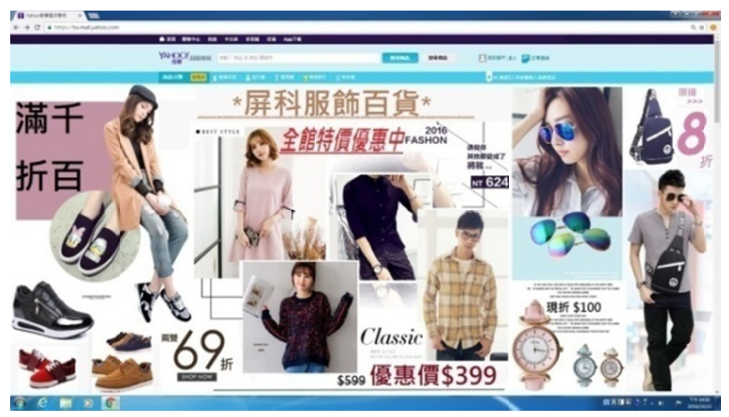

Figure 7. Pay less manipulation in clothing

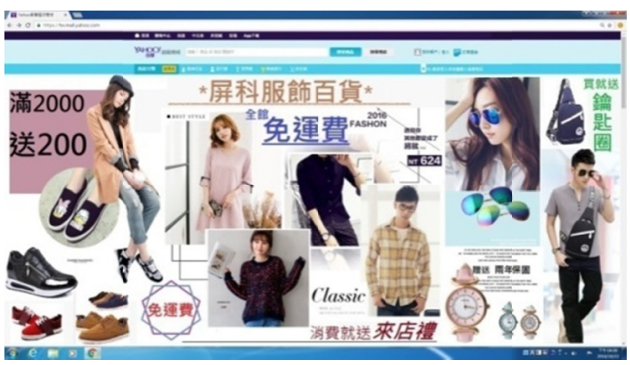

Figure 9. Get more manipulation in clothing

\section{Sample size}

According to Hair (2010), sample size is estimated by at least 15 observations for each independent variable. It requires at least 30 samples for each experimental group. A total of 435 subjects participated in this study in 4 days total in 2016. There were 25 invalid responses. The rest 410 sample sizes were used for analysis as shown 
in Table 4. In the past, online shopping was dominated by the young people, but in recent years it was found that online customers are more diverse. This may be due to the gradually increase of online shopping making online shopping no longer dominated by a specific group. Nowadays, students are heavily involved in online shopping for reasons being flexibility and convenience. This research focused on university students who have been used in many previous studies (J. Lee, Sun, \& Lebanon, 2012; Zhang et al., 2011).

Table 4. Sample distribution

\begin{tabular}{llll}
\hline Rarity manipulation & Sample & Mental accounting manipulation & Sample \\
\hline No manipulation & 102 & No manipulation & 103 \\
Limited time & & Pay less & 102 \\
No manipulation & 103 & No manipulation & $\mathbf{2 0 5}$ \\
Limited quantity & $\mathbf{2 0 5}$ & Get more & Total \\
Total & & &
\end{tabular}

\subsection{Data Analysis}

In the following section, Cronbach's alpha was used to evaluate the reliability and validity of the variables. Analysis of moment structure (AMOS 22.0) and STATISTICA 9.0 software were used to test the research hypotheses.

To test the internal consistency of the indicators of each factor, the most common method was to calculate the Cronbach's alpha value. As shown in Table 5, Cronbach's $\alpha$ values were calculated for internal validity, the values ranged from 0.707 to 0.941 . Hair (2010) suggested that $\alpha$ value should higher than 0.700 . Therefore, all measurements were internally consistent and reliable.

Table 5.Cronbach's $\alpha$ value

\begin{tabular}{|c|c|c|c|c|c|c|}
\hline \multirow{2}{*}{ Content } & \multirow{2}{*}{$\begin{array}{l}\text { Number } \\
\text { question }\end{array}$} & \multirow[t]{2}{*}{ of } & \multicolumn{2}{|l|}{ Rarity } & \multicolumn{2}{|l|}{$\begin{array}{l}\text { Mental accounting } \\
\text { Cronbach's } \alpha \text { Value }\end{array}$} \\
\hline & & & No manipulation & $\begin{array}{l}\text { Have } \\
\text { manipulation }\end{array}$ & No manipulation & Have manipulation \\
\hline Search Costs $X_{1}$ & 3 & & 0.707 & 0.736 & 0.750 & 0.748 \\
\hline Perceived Risk $\mathrm{X}_{2}$ & 4 & & 0.822 & 0.840 & 0.833 & 0.888 \\
\hline Purchase Intention Y & 4 & & 0.919 & 0.941 & 0.942 & 0.932 \\
\hline
\end{tabular}

\section{Results and Discussion}

\subsection{Effect of Search Costs and Perceived Risk Influence on Online Purchase Intention}

Pearson correlation and mean analysis were used to analyze the inter-correlation among model variables. The correlation coefficient was used to explain the correlation among variables. Mean and standard deviation are also presented.

Table 6. Inter-correlation among model variables

\begin{tabular}{|c|c|c|c|c|c|}
\hline & Mean & Std & Search costs & Perceived risk & Purchase intention \\
\hline \multicolumn{6}{|c|}{ Without rarity manipulation } \\
\hline Search costs $\left(\mathrm{X}_{1}\right)$ & 4.289 & 1.10223 & 1 & & \\
\hline Perceived risk $\left(\mathrm{X}_{2}\right)$ & 5.515 & 0.91843 & $0.282^{* *}$ & 1 & \\
\hline Purchase intention $(\mathrm{Y})$ & 4.626 & 1.06366 & -0.103 & -0.049 & 1 \\
\hline \multicolumn{6}{|c|}{ With rarity manipulation } \\
\hline Search costs $\left(\mathrm{X}_{1}\right)$ & 4.340 & 1.07720 & 1 & & \\
\hline Perceived risk $\left(\mathrm{X}_{2}\right)$ & 5.484 & 0.86626 & $0.179^{*}$ & 1 & \\
\hline Purchase intention (Y) & 4.717 & 1.06539 & $0.193^{* *}$ & $0.310^{* *}$ & 1 \\
\hline
\end{tabular}


As shown in table 6 , the correlation coefficients without rarity moderator effect were $0.282,-0.103$ and -0.049 , respectively. Firstly, search costs had a positive correlation and a significant effect with the perceived risk. Secondly, the search costs and purchase intention were negatively correlated; indicating respondents believed that the higher the search costs, the lower the purchase intention. Thirdly, perceived risk was negatively related to the willingness to buy, indicating that the subjects alleged the higher the perceived risk, the decreased willingness to buy, and will not be much affected. Therefore, there was no significant effect of search costs and perceived risk on purchase intention, but with rarity moderator, search costs has a significant effect on the purchase intention.

The correlation coefficients under the rarity moderator effect were $0.179,0.193$ and 0.310 respectively. Search costs are positively correlated and have a significant effect. Search costs and perceived risk are positively correlated and have a significant effect on customers the purchase intention. These results indicate that the subjects in the case of rarity effect, no matter how high search costs or perceived risk is, they will be willing to buy. There was no significant effect of search costs and perceived risk on purchase intention, but with an interruption of rarity, search costs and perceived risk had a significant effect on purchase intention. The correlation coefficient between independent variables and dependent variable went from negative to a positive correlation after having an interruption of rarity. Moreover, the mean of purchase intention increased from 4.626 to 4.717 under rarity moderator effect. Consequently, hypothesis $\mathrm{H}_{1-1}$ was rejected.

Table 7. Inter-correlation among model variable

\begin{tabular}{|c|c|c|c|c|c|}
\hline & Mean & Std & Search costs & Perceived risk & Purchase intention \\
\hline \multicolumn{6}{|c|}{ Without mental accounting manipulation } \\
\hline Search costs $\left(\mathrm{X}_{1}\right)$ & 4.415 & 1.02616 & 1 & & \\
\hline Perceived risk $\left(\mathrm{X}_{2}\right)$ & 5.478 & 0.85072 & $0.236^{* *}$ & 1 & \\
\hline Purchase intention $(\mathrm{Y})$ & 4.967 & 1.01459 & -0.038 & -0.077 & 1 \\
\hline \multicolumn{6}{|c|}{ With mental accounting manipulation } \\
\hline Search costs $\left(\mathrm{X}_{1}\right)$ & 4.374 & 1.06972 & 1 & & \\
\hline Perceived risk $\left(\mathrm{X}_{2}\right)$ & 5.402 & 0.90934 & $0.207^{* *}$ & 1 & \\
\hline Purchase intention (Y) & 5.098 & 0.92481 & $0.256^{* *}$ & $0.460^{* *}$ & 1 \\
\hline
\end{tabular}

As shown in table 7, the correlation coefficients under the heading without mental accounting condition were $0.236,-0.038$ and -0.077 , respectively. Search costs had a positive correlation and a significant effect on the perceived risk. Furthermore, search costs and purchase intention are negatively correlated; indicating respondents believe that the higher the search costs, the lower the purchase intention. Additionally, perceived risk is negatively related to the willingness to buy, indicating that the subject perceives the higher the perceived risk, the willingness to buy decreases, and will not be much affected.

The correlation coefficients under mental accounting condition were $0.207,0.256$ and 0.460 , respectively. Search costs are positively correlated with a significant effect. Search costs and perceived risk are positively correlated and had a significant effect with the purchase intention. The results indicated that the subjects in the case of rarity effect, no matter how high search costs or perceived risk is, they will be willing to buy. The mean of purchase intention increased from 4.967 to 5.098 under the mental accounting moderator effect. Moreover, the correlation coefficient between independent variables and dependent variable changed from a negative to a positive correlation after interruption by mental accounting. There is no significant effect of search costs and perceived risk on purchase intention, but with mental account moderator, search costs and perceived risk have a significant effect on the purchase intention. Consequently, hypothesis $\mathrm{H}_{1-2}$ was rejected.

\subsection{The Moderator Effect of Rarity}

This study divides the rarity into two categories: limited time and limited quantity, and compares the impact of search costs and perceived risk on online purchase intention under manipulation and have manipulation. In the following study, path analysis and Fisher's $Z$ test were used to investigate the moderator effect of rarity. 
Table 8. Path analysis results for rarity manipulation

\begin{tabular}{llllll}
\hline & Path & Standardization estimate value Non-standardization estimate value Standard error $\boldsymbol{t}$-value & Adj. $\boldsymbol{R}^{\mathbf{2}}$ \\
\hline \multirow{2}{*}{ No moderator } & $\mathrm{X}_{1} \rightarrow \mathrm{Y}-0.126$ & -0.122 & 0.067 & -1.821 & 0.323 \\
& $\mathrm{X}_{2} \rightarrow \mathrm{Y}-0.084$ & -0.098 & 0.080 & -1.215 & 0.32 \\
\multirow{2}{*}{ Limited time } & $\mathrm{X}_{1} \rightarrow \mathrm{Y} 0.283$ & 0.265 & 0.082 & $3.222^{* * *}$ \\
& $\mathrm{X}_{2} \rightarrow \mathrm{Y} 0.371$ & 0.505 & 0.120 & $4.218^{* * *} 0.518$ \\
\multirow{2}{*}{ Limited quantity } & $\mathrm{X}_{1} \rightarrow \mathrm{Y} 0.011$ & 0.010 & 0.094 & 0.111 \\
& $\mathrm{X}_{2} \rightarrow \mathrm{Y} 0.164$ & 0.180 & 0.107 & 1.685 & 0.307 \\
\hline
\end{tabular}

Note: $* p<0.05, * * p<0.01, * * * p<0.001$.

$\mathrm{X}_{1} \rightarrow \mathrm{Y}$ : Search costs $\rightarrow$ Purchase intention; $\mathrm{X}_{2} \rightarrow \mathrm{Y}$ : Perceived risk $\rightarrow$ Purchase intention.

Path analysis, shown in table 8 displays that in the absence of rarity manipulation, the search costs and perceived risk have no significant effect on online purchase intention $(\beta=-0.126, t=-1.821 ; \beta=-0.084, t=-1.215)$. Under limited time, the search costs and perceived risk have a positive and significant effects on the online purchase intention ( $\beta=0.283, t=3.222 * * * ; \beta=0.371, t=4.218 * * *)$, indicating that higher search costs and perceived risk increases online purchase intention. Under limited quantity, the search costs and perceived risk have no significant effects on the online purchase intention $(\beta=0.011, t=0.111 ; \beta=0.164, t=1.685)$.

Table 9. Comparison table Fisher's $Z$ test under rarity manipulation

\begin{tabular}{|c|c|c|c|c|c|}
\hline & Correlation coefficient $\left(X_{1}, Y\right)$ & $Z$-value & Correlation coefficient $\left(\mathrm{X}_{2}, \mathrm{Y}\right)$ & Z-value & Sample \\
\hline Limited time & $\mathrm{r} 1\left(\mathrm{X}_{1}, \mathrm{Y}\right)=0.350^{* *}$ & & $\mathrm{r} 1\left(\mathrm{X}_{2}, \mathrm{Y}\right)=0.418^{* *}$ & & \\
\hline $\begin{array}{l}\text { vs. } \\
\text { No manipulation }\end{array}$ & $\mathrm{r} 0\left(\mathrm{X}_{1}, \mathrm{Y}\right)=-0.273^{* *}$ & $4.542^{* * *}$ & $\mathrm{r} 0\left(\mathrm{X}_{2}, \mathrm{Y}\right)=-0.06$ & $3.55^{* * *}$ & 102 \\
\hline Limited quantity & $\mathrm{r} 2\left(\mathrm{X}_{1}, \mathrm{Y}\right)=0.037$ & & $\mathrm{r} 2\left(\mathrm{X}_{2}, \mathrm{Y}\right)=0.166$ & & \\
\hline $\begin{array}{l}\text { vs. } \\
\text { No manipulation }\end{array}$ & $\mathrm{r} 0\left(\mathrm{X}_{1}, \mathrm{Y}\right)=0.087$ & -0.355 & $\mathrm{r} 0\left(\mathrm{X}_{2}, \mathrm{Y}\right)=0.123$ & 0.31 & 103 \\
\hline Limited time & $\mathrm{r} 1\left(\mathrm{X}_{1}, \mathrm{Y}\right)=0.350^{* *}$ & & $\mathrm{r} 1\left(\mathrm{X}_{2}, \mathrm{Y}\right)=0.418^{* *}$ & & 102 \\
\hline $\begin{array}{l}\text { vs. } \\
\text { Limited quantity }\end{array}$ & $\mathrm{r} 2\left(\mathrm{X}_{1}, \mathrm{Y}\right)=0.037$ & $2.316^{*}$ & $\mathrm{r} 2\left(\mathrm{X}_{2}, \mathrm{Y}\right)=0.166$ & $1.96^{*}$ & 103 \\
\hline
\end{tabular}

Limited time manipulation, $\mathrm{r} 2\left(\mathrm{X}_{2}, \mathrm{Y}\right)$ : Limited quantity manipulation.

In order to compare different moderation effect of rarity between search costs, perceived risk and purchase intention, Fisher's $Z$ test was used and shown in table 9, Figure 10 and Figure 11. The limited time effect had a significant adjustment effect to the impact of search costs and perceived risk on purchase intention $\left(\mathrm{Z}=4.54^{* * *}\right.$ and $\mathrm{Z}=3.55^{* * *}$ respectively). Hence, the hypotheses $\mathrm{H}_{2-1}$ and $\mathrm{H}_{2-2}$ were supported. However, the limited quantity effect had no significant effect on the influence of search costs and perceived risk on purchase intention $(Z=$ $-0.355 ; \mathrm{Z}=0.310$ respectively). Therefore, hypotheses $\mathrm{H}_{2-3}$ and $\mathrm{H}_{2-4}$ were rejected. There are different moderation effects of limited time and limited quantity $\left(Z=2.316^{*} ; Z=1.96^{*}\right)$. Limited time rarity created greater sense of competition and thereby it has higher significant adjustment effect. It is possible that customers feel an implicit time limitation of the competition they perceive with other buyers. While Aggarwal et al. (2011) argued that consumers' responses have stronger effect by the limited-quantity than limited-time. 


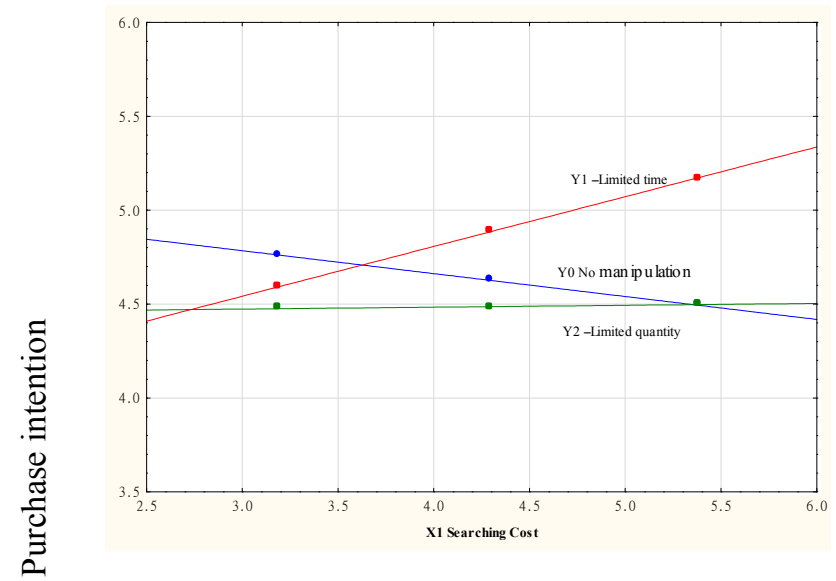

Figure 10. The effect of search costs on the purchase intention under rarity manipulation

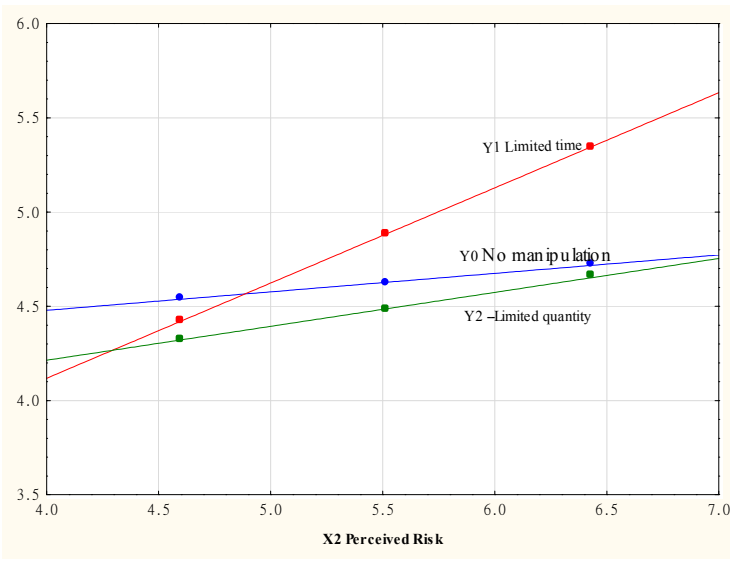

Figure 11. The effect of perceived risk on the purchase intention under rarity manipulation

The impact of search costs and perceived risk on purchase intention under no manipulation and different moderation effect on rarity are shown in Figure 10 and Figure 11. The search costs $(\mathrm{M}=4.289, \mathrm{Std}=1.102)$ and perceived risk $(M=5.515, \mathrm{Std}=0.918)$ are represented on the horizontal axis. It is clear that limited time has positive and strong significant adjustment effect on the impact of search costs on purchase intention. Limited time adjustment effect is stronger than other adjustment effect under moderator effect of limited quantity or no manipulation. Although search costs are getting higher but under limited time condition, it also improves online customer purchase intention.

\subsection{The Moderator Effect of Mental Accounting}

Mental accounting is divided into two categories: pay less and get more. In the following table, path analysis and Fisher's $\mathrm{Z}$ test were used to investigate moderator effect of rarity and comparing the impact of search costs and perceived risk on online purchase intention in under manipulation and have manipulation.

Table 10. Path analysis results for mental accounting manipulation

\begin{tabular}{|c|c|c|c|c|c|c|}
\hline & Path & Standardization estimate value & Non-standardization estimate value & Standard error & $t$-value & Adj. $R^{2}$ \\
\hline \multirow{2}{*}{ No manipulation } & $\mathrm{X}_{1} \rightarrow \mathrm{Y}$ & -0.059 & -0.058 & 0.069 & -0.847 & \multirow{2}{*}{0.312} \\
\hline & $\mathrm{X}_{2} \rightarrow \mathrm{Y}$ & -0.091 & -0.108 & 0.083 & -1.299 & \\
\hline \multirow{2}{*}{ Pay less } & $\mathrm{X}_{1} \rightarrow \mathrm{Y}$ & 0.193 & 0.161 & 0.077 & $2.098^{*}$ & \multirow{2}{*}{0.519} \\
\hline & $\mathrm{X}_{2} \rightarrow \mathrm{Y}$ & 0.319 & 0.266 & 0.077 & $3.472^{* * *}$ & \\
\hline \multirow{2}{*}{ Get more } & $\mathrm{X}_{1} \rightarrow \mathrm{Y}$ & 0.172 & 0.149 & 0.071 & $2.089^{*}$ & \multirow{2}{*}{0.531} \\
\hline & $\mathrm{X}_{2} \rightarrow \mathrm{Y}$ & 0.530 & 0.679 & 0.106 & $6.422^{* * *}$ & \\
\hline
\end{tabular}

Note: $* p<0.05, * * p<0.01, * * * p<0.001$;

$\mathrm{X}_{1} \rightarrow \mathrm{Y}:$ Search costs $\rightarrow$ Purchase intention; $\mathrm{X}_{2} \rightarrow \mathrm{Y}$ : Perceived risk $\rightarrow$ Purchase intention

Path analysis results shown in table 10 shows that in the absence of mental accounting manipulation, the search costs and perceived risk have no significant effect on online purchase intention $(\beta=-0.059, t=-0.847 ; \beta=-0.091$, $t=-1.299)$. Under pay less, the search costs and perceived risk have positive and significant effects on the online purchase intention $(\beta=0.193, t=2.098 * ; \beta=0.319, t=3.472 * * *)$, indicating that the higher search costs and perceived risk are, the more online purchase will be. Under get more, the search costs and perceived risk have positive significant effects on the online purchase intention $(\beta=0.172, t=2.089 * ; \beta=0.530, t=6.422 * * *)$. 
Table 11. Comparison table Fisher's Z test under mental accounting manipulation

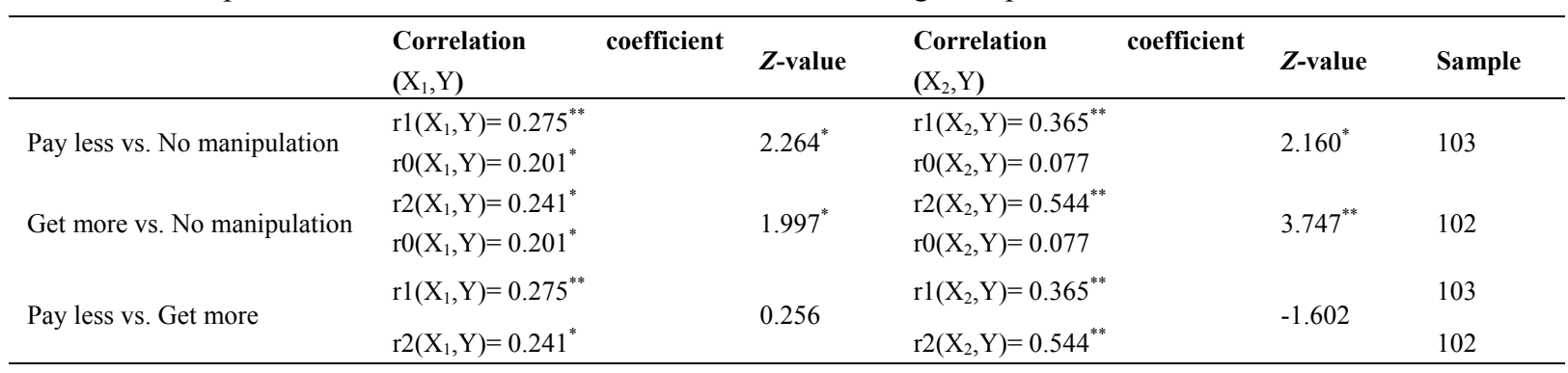

Note: $* p<0.05, * * p<0.01, * * * p<0.001 . \mathrm{X}_{1}$ : Search costs; $\mathrm{X}_{2}$ : Perceived risk; Y: Purchase intention;

$\mathrm{r} 0\left(\mathrm{X}_{1}, \mathrm{Y}\right)$ : No manipulation, $\mathrm{r} 1\left(\mathrm{X}_{1}, \mathrm{Y}\right)$ : Pay less manipulation, $\mathrm{r} 2\left(\mathrm{X}_{1}, \mathrm{Y}\right)$ :Get more manipulation.

In order to confirm the impact of search costs and perceived risk on online purchase intention under different conditions of mental accounting, Fisher's $Z$ test was performed in table 11. There is no significant difference between pay less and get more $(Z=0.256 ; Z=-1.602)$. The pay less effect has significant adjustment effect to the impact of search costs and perceived risk on purchase intention $(Z=2.264 *$ and $Z=2.160 *$, respectively). Hence, the hypotheses $\mathrm{H}_{3-1}$ and $\mathrm{H}_{3-2}$ were supported. The get more effect had a positive and a significant effect on the influence of search costs and perceived risk on purchase intention $\left(Z=1.997^{*} ; Z=3.747^{*}\right.$ respectively). Therefore, hypotheses $\mathrm{H}_{3-3}$ and $\mathrm{H}_{3-4}$ were rejected. Liu and Chiu (2015) suggested that get more (ex. Buy one, get one free) is much more attractive. However, this study explored that there are not significant different between two kinds of mental accounting condition. Therefore, in general, companies can vary their promotional formats for customers have their reference price for the target product.

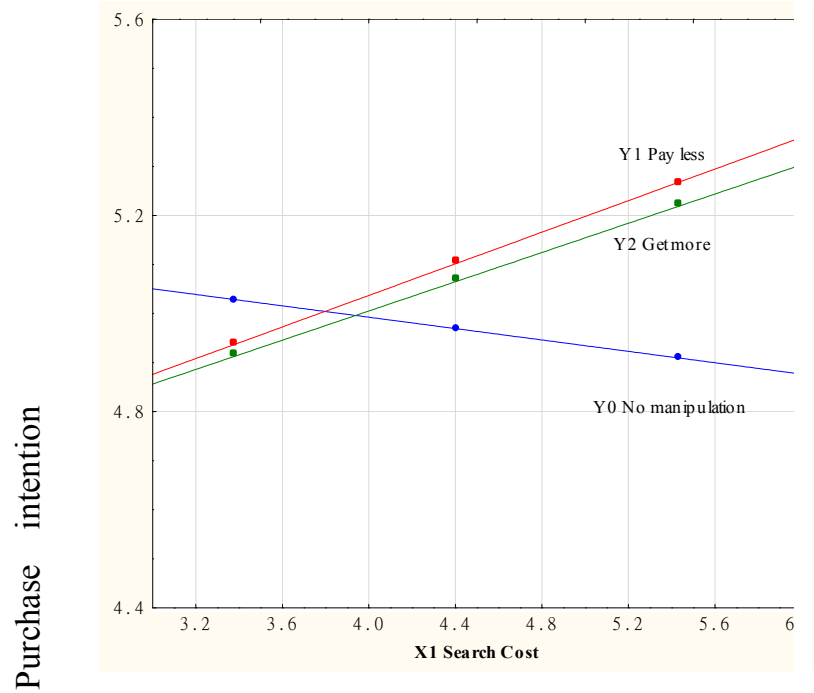

Figure 12. The effect of search costs on the purchase Fig intention under mental accounting manipulation

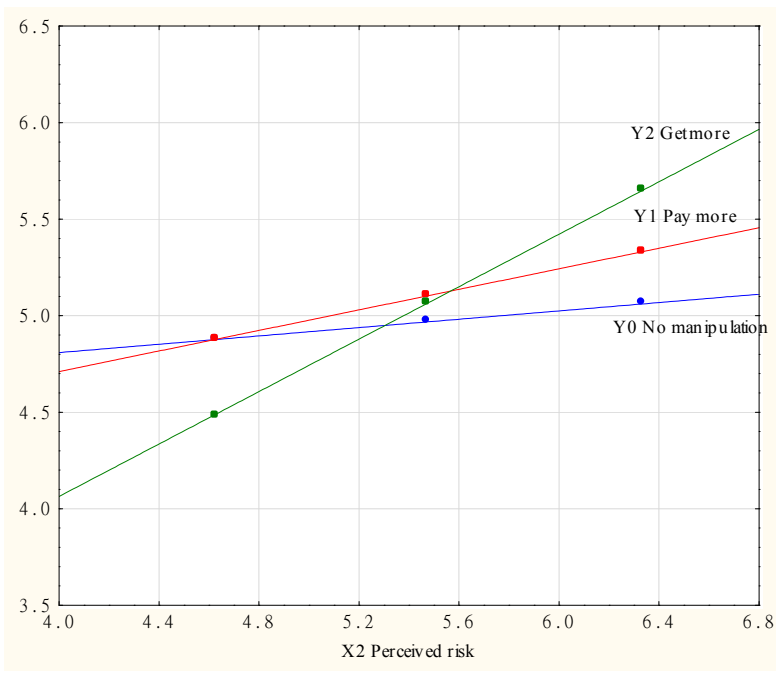

intention under mental accounting manipulation

Figure 12 and Figure 13 show the impact of search costs and perceived risk on purchase intention under no manipulation and different moderator effect of mental accounting. The search costs $(M=4.415, \mathrm{Std}=1.026)$ and perceived risk $(\mathrm{M}=5.478, \mathrm{Std}=0.815)$ are represented on the horizontal axis. Comparing with no manipulation, pay less and get more significantly adjustment impact on the influence of search costs and perceived risk on purchase intention. However, there are no significant differences between adjustment effects of pay less and get more. Therefore, online customer purchase intention will also improve under metal account (pay less or get more) condition although they are faced with high search costs or high perceived risk.

\section{Conclusions}

The aim of this study was to explore the impact of search costs and perceived risk on online buying intentions under the moderator of rarity and mental accounting in marketing practices. 
Under no manipulation, search costs and perceived risk had no significant effects on purchasing intention. But with moderators of rarity and mental accounting, search costs and perceived risks positively influenced online purchase intention, indicating that the customers believe that the higher search costs and perceived risk increases purchase intention under rarity and mental accounting condition. It may be due to online customers spending their time and effort to find the products or uncertain information of products or services. This study suggests that websites should provide accurate product names, so that customers can find product information quickly. By providing return policy or detailed procedures with clearly labeled products, e-vendors can reduce the risk and consumers may have on-line shopping in order to increase their willingness to buy.

The rarity acts as a significant moderator on the impact of search costs and perceived risk on purchase intention, indicating that when an e-vendor operates limited time or limited quantity program, customers will have positive purchase intention even they feel high search costs or perceived risk. Moreover, comparing two kinds of rarity moderator effect on impact of search costs and perceived risk on online buying intention, limited time is more significant moderator than limited quantity. Therefore, e-vendors can base on these results to launch suitable promotional programs to improve customers' desire. It is more important to select the kind of appreciated rarity signal to the type of product. Moreover, in the case of limited quantity, the units can be numbered sequentially to strengthen the feelings of unique. This study suggests that e-vendors can use rarity of time and quantity to promote the product, during a launched festival with the festival-related products, such as: Christmas in the launch of the exclusive Christmas dessert; or seasonal products in the four seasons. In addition companies can control the number of products in a certain range, so that the number of products in the market circulations the demand is more than supply, such as: limited edition of 50 sets or issued with well-known brands of limited joint products.

The mental accounting acts as significant moderator on the impact of search costs and perceived risk on purchase intention. It means when e-vendors use mental accounting program (pay less or get more), even if they believe high search costs or high perceived risk, online customers still have positive purchasing intention. This study suggests that the e-vendors can use mental accounting the pay less method to promote the product, when spending a certain amount of cash discount or can give additional services or coupons, such as a free service or a small gift to attract consumers or providing after-sales service with expensive products.

The research model that was estimated in this study provides practical implications in the e-commerce field and help to the practice of rarity and mental accounting on customers purchase intention. In addition, this study examined the impact of search costs and perceived risk under condition of rarity and mental accounting.

This research has certain limitations. Firstly, the study products were specified for online shopping with an age range from 15 to 25 years old which are objects of this study. The results cannot represent the views of all consumers, so the conclusion of the study is generally limited. Further research may be needed to study different age group with representative products. Secondly, the analysis method of this study is only carried out by quantitative analysis, not included in the qualitative research, which may make the results of data analysis inference is inadequate.

\section{References}

Aggarwal, P., Jun, S. Y., \& Huh, J. H. (2011). Scarcity messages. Journal of Advertising, 40(3), 19-30. http://dx.doi.org/10.2753/JOA0091-3367400302

Amaldoss, W., \& Jain, S. (2005). Conspicuous consumption and sophisticated thinking. Management Science, 51(10), 1449-1466. https://doi.org/10.1287/mnsc.1050.0399

Beatty, S. E., \& Smith, S. M. (1987). External search effort: An investigation across several product categories. Journal of Consumer Research, 14(1), 83-95. https://doi.org/10.1086/209095

Bettman, J. R. (1979). Information processing theory of consumer choice: Addison-Wesley Pub. Co.

Bhattacherjee, A. (2002). Individual trust in online firms: Scale development and initial test. Journal of management information systems, 19(1), 211-241. http://dx.doi.org/10.1080/07421222.2002.11045715

Brannon, L. A., \& Brock, T. C. (2001). Limiting time for responding enhances behavior corresponding to the merits of compliance appeals: Refutations of heuristic-cue theory in service and consumer settings. Journal of Consumer Psychology, 10(3), 135-146. https://doi.org/10.1207/s15327663jcp1003_2

Campbell, L., \& Diamond, W. D. (1990). Framing and Sales Promotions: The Characteristics of a "Good Deal ". Journal of Consumer Marketing, 7(4), 25-31. https://doi.org/10.1108/EUM0000000002586

Castro, I. A., Morales, A. C., \& Nowlis, S. M. (2013, July). The influence of disorganized shelf displays and 
limited product quantity on consumer purchase. American Marketing Association.

Cooper, D. R., Schindler, P. S., \& Sun, J. (2003). Business research methods. London, England: Pearson Education.

Dodds, W. B., Monroe, K. B., \& Grewal, D. (1991). Effects of price, brand, and store information on buyers' product evaluations. Journal of Marketing Research, 307-319.

Duxbury, D., Keasey, K., Zhang, H., \& Chow, S. L. (2005). Mental accounting and decision making: Evidence under reverse conditions where money is spent for time saved. Journal of Economic Psychology, 26(4), 567-580. https://doi.org/10.1016/j.joep.2004.11.001

Ehrenberg, A. S. (2000). Repetitive advertising and the consumer. Journal of Advertising Research, 40(6), 39-48. https://doi.org/10.2501/JAR-40-6-39-48

Featherman, M. S., \& Pavlou, P. A. (2003). Predicting e-services adoption: a perceived risk facets perspective. International journal of human-computer studies, 59(4), 451-474. https://doi.org/10.1016/S1071-5819(03)00111-3

Forsythe, S. M., \& Shi, B. (2003). Consumer patronage and risk perceptions in Internet shopping. Journal of Business Research, 56(11), 867-875. https://doi.org/10.1016/S0148-2963(01)00273-9

Fry, J. N., \& McDougall, G. H. (1974). Consumer appraisal of retail price advertisements. The Journal of Marketing, 64-67.

Garbarino, E., \& Strahilevitz, M. (2004). Gender differences in the perceived risk of buying online and the effects of receiving a site recommendation. Journal of Business Research, 57(7), 768-775. https://doi.org/10.1016/S0148-2963(02)00363-6

Gierl, H., \& Huettl, V. (2010). Are scarce products always more attractive? The interaction of different types of scarcity signals with products' suitability for conspicuous consumption. International Journal of Research in Marketing, 27(3), 225-235. https://doi.org/10.1016/j.ijresmar.2010.02.002

Gierl, H., Plantsch, M., \& Schweidler, J. (2008). Scarcity effects on sales volume in retail. The International Review of Retail, Distribution and Consumer Research, 18(1), 45-61. http://dx.doi.org/10.1080/09593960701778077

Greenwald, A. G. (1968). Cognitive learning, cognitive response to persuasion, and attitude change. Psychological foundations of attitudes, 147-170.

Hair, J. F. (2010). Multivariate data analysis. NJ, USA: Pearson College Division.

Helion, C., \& Gilovich, T. (2014). Gift Cards and Mental Accounting: Green - lighting Hedonic Spending. Journal of Behavioral decision making, 27(4), https://doi.org/386-393. 10.1002/bdm.1813

Ho Ha, H., Suk Hyun, J., \& Pae, J. H. (2006). Consumers'“mental accounting” in response to unexpected price savings at the point of sale. Marketing Intelligence \& Planning, 24(4), 406-416. https://doi.org/10.1108/02634500610672134

Jung, J. M., \& Kellaris, J. J. (2004). Cross - national differences in proneness to scarcity effects: The moderating roles of familiarity, uncertainty avoidance, and need for cognitive closure. Psychology \& Marketing, 21(9), 739-753. https://doi.org/10.1002/mar.20027

Kim, J., \& Lennon, S. J. (2013). Effects of reputation and website quality on online consumers' emotion, perceived risk and purchase intention: Based on the stimulus - organism - response model. Journal of Research in Interactive Marketing, 7(1), 33-56. doi: doi:10.1108/17505931311316734

Kuhlmeier, D., \& Knight, G. (2005). Antecedents to internet-based purchasing: a multinational study. International Marketing Review, 22(4), 460-473. https://doi.org/10.1108/02651330510608460

Lee, J., Sun, M., \& Lebanon, G. (2012). Prea: Personalized recommendation algorithms toolkit. Journal of Machine Learning Research, 13(Sep), 2699-2703.

Lee, T.R., Lin, J.H., Liao, L. W.C., \& Yeh, T.H. (2013). Managing the positive and negative characteristics of enterprise microblog to attract user to take action through the perspective of behavioural response. International Journal of Management and Enterprise Development, 12(4-6), 363-384. https://doi.org/10.1504/IJMED.2013.056443

Liang, T.P., \& Huang, J.S. (1998). An empirical study on consumer acceptance of products in electronic markets: a transaction cost model. Decision Support Systems, 24(1), 29-43. 
https://doi.org/10.1016/S0167-9236(98)00061-X

Liao, S., \& Chu, H. (2013). Influence of consumer online resale awareness on purchase decisions: a mental accounting perspective. European Journal of marketing, 47(10), 1576-1597. https://doi.org/10.1108/EJM-12-2010-0665

Liu, H.-H., \& Chiu, Y.-Y. (2015). Sales framing, mental accounting, and discount assignments. Asia Pacific Management Review, 20(4), 201-209. https://doi.org/10.1016/j.apmrv.2015.01.002

Lynch Jr, J. G., \& Ariely, D. (2000). Wine online: Search costs affect competition on price, quality, and distribution. Marketing Science, 19(1), 83-103. https://doi.org/10.1287/mksc.19.1.83.15183

Morwitz, V. G., \& Schmittlein, D. (1992). Using segmentation to improve sales forecasts based on purchase intent: Which" intenders" actually buy? Journal of Marketing Research, 391-405.

Pires, G., Stanton, J., \& Eckford, A. (2004). Influences on the perceived risk of purchasing online. Journal of consumer behaviour, 4(2), https://doi.org/118-131. 10.1002/cb.163

Ratchford, B. T. (1982). Cost-benefit models for explaining consumer choice and information seeking behavior. Management Science, 28(2), 197-212. https://doi.org/10.1287/mnsc.28.2.197

Reinholtz, N., Bartels, D. M., \& Parker, J. R. (2015). On the mental accounting of restricted-use funds: How gift cards change what people purchase. Journal of Consumer Research. https://doi.org/10.1093/jcr/ucv045

Schmidt, J. B., \& Spreng, R. A. (1996). A proposed model of external consumer information search. Journal of the academy of marketing science, 24(3), 246-256.

Simonson, I. (1992). The influence of anticipating regret and responsibility on purchase decisions. Journal of Consumer Research, 19(1), 105-118. https://doi.org/10.1086/209290

Srinivasan, N., \& Ratchford, B. T. (1991). An empirical test of a model of external search for automobiles. Journal of Consumer Research, 18(2), 233-242. https://doi.org/10.1086/209255

Stone, R. N., \& Grønhaug, K. (1993). Perceived risk: Further considerations for the marketing discipline. European Journal of marketing, 27(3), 39-50. https://doi.org/10.1108/03090569310026637

Teo, T. S., \& Yu, Y. (2005). Online buying behavior: a transaction cost economics perspective. Omega, 33(5), 451-465. https://doi.org/10.1016/j.omega.2004.06.002

Thaler, R. (1985). Mental accounting and consumer choice. Marketing Science, 4(3), 199-214. https://doi.org/10.1287/mksc.4.3.199

Verhallen, T. M. (1982). Scarcity and consumer choice behavior. Journal of Economic Psychology, 2(4), 299-322. https://doi.org/10.1016/0167-4870(82)90034-4

Verhallen, T. M., \& Robben, H. S. (1994). Scarcity and preference: An experiment on unavailability and product $\begin{array}{lllll}\text { evaluation. Journal of } & \text { Economic }\end{array}$ https://doi.org/10.1016/0167-4870(94)90007-8

Wigand, R. T. (1997). Electronic commerce: Definition, theory, and context. The information society, 13(1), 1-16. http://dx.doi.org/10.1080/019722497129241

Wu, W. Y., Lu, H. Y., Wu, Y. Y., \& Fu, C. S. (2012). The effects of product scarcity and consumers' need for uniqueness on purchase intention. International Journal of Consumer Studies, 36(3), 263-274. https://doi.org/10.1111/j.1470-6431.2011.01000.x

Xiao, S. H., \& Nicholson, M. (2013). A multidisciplinary cognitive behavioural framework of impulse buying: A systematic review of the literature. International Journal of Management Reviews, 15(3), 333-356. 10.1111/j.1468-2370.2012.00345.x

Zeithaml, V. A. (1988). Consumer perceptions of price, quality, and value: a means-end model and synthesis of evidence. The Journal of Marketing, 2-22.

Zhang, Y., Fang, Y., Wei, K.-K., Ramsey, E., McCole, P., \& Chen, H. (2011). Repurchase intention in B2C e-commerce-A relationship quality perspective. Information \& Management, 48(6), 192-200. https://doi.org/10.1016/j.im.2011.05.003 


\section{Copyrights}

Copyright for this article is retained by the author(s), with first publication rights granted to the journal.

This is an open-access article distributed under the terms and conditions of the Creative Commons Attribution license (http://creativecommons.org/licenses/by/4.0/). 